\title{
The Science of Theology according to Richard Fishacre: Edition of the Prologue to his Commentary on the Sentences
}

\author{
R. James Long \\ Fairfield University, rjlong@fairfield.edu
}

Follow this and additional works at: https://digitalcommons.fairfield.edu/philosophy-facultypubs Copyright 1972 Pontifical Institute of Mediaeval Studies

\section{Peer Reviewed}

\section{Repository Citation}

Long, R. James, "The Science of Theology according to Richard Fishacre: Edition of the Prologue to his Commentary on the Sentences" (1972). Philosophy Faculty Publications. 17.

https://digitalcommons.fairfield.edu/philosophy-facultypubs/17

\section{Published Citation}

Long, R. James (1972) "The Science of Theology according to Richard Fishacre: Edition of the Prologue to his Commentary on the Sentences," Mediaeval Studies 34 (1972) 7198.

This item has been accepted for inclusion in DigitalCommons@Fairfield by an authorized administrator of DigitalCommons@Fairfield. It is brought to you by DigitalCommons@Fairfield with permission from the rightsholder(s) and is protected by copyright and/or related rights. You are free to use this item in any way that is permitted by the copyright and related rights legislation that applies to your use. For other uses, you need to obtain permission from the rights-holder(s) directly, unless additional rights are indicated by a Creative Commons license in the record and/or on the work itself. For more information, please contact digitalcommons@fairfield.edu. 
An Offprint from

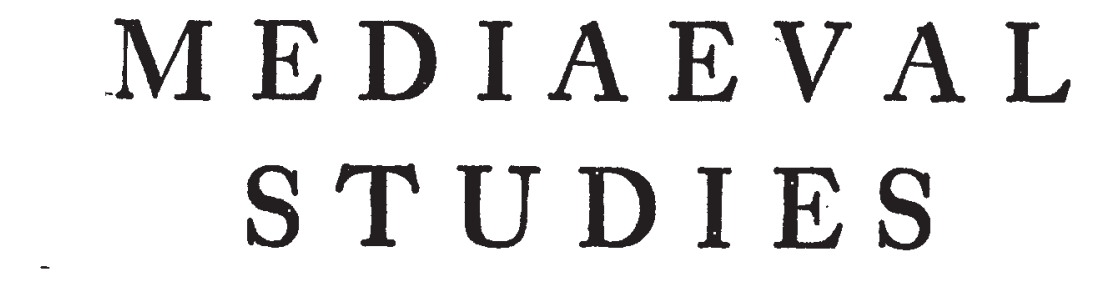

Volume $X X X I V$

1972

THE SGIENGE OF THEOLOGY

AGCORDING TO RICHARD FISHAGRE :

EDITION OF THE PROLOGUE TO HIS COMMENTARY

ON THE SENTENCES

By R. James Long

PONTIFICAL INSTITUTE OF MEDIAEVAL STUDIES TORONTO, GANADA 


\title{
THE SGIENGE OF THEOLOGY
}

ACCORDING TO RICHARD FISHAGRE :

\author{
EDITION OF THE PROLOGUE TO HIS COMMENTARY \\ ON THE SENTECES
}

R. James Long

$\mathrm{B}^{\mathrm{s}}$ EFORE composing his monumental Commentary on the Sentences, the Dominican theologian Richard Fischacre (d. 1248) set down in a Prologue his concept of the nature and domain of the science he was about to practise. This Prologue, aside from introducing the first Sentence-Commentary written at Oxford, ${ }^{1}$ is significant in that it heralded at that university a new theological method.

Twelfth-century commentaries on Scripture had been quite unspecialized, containing both doctrinal teaching - often in the form of quaestiones - and moral instruction. About the turn of the century, however, the masters of Paris gradually adopted a more specialized approach, excluding the quaestiones from their lectures on Scripture in order to concentrate on exegesis and moral exhortation. Doctrinal discussions, on the other hand, were relegated almost exclusively to the lectures on the Sentences. ${ }^{2}$

Fishacre, who was the first Dominican to incept at Oxford, greets this "new theology" with approval. Theology has two parts, he writes in his

1 D. Callus, Introduction of Aristotelian Learning to Oxford (London, 1943), 32. Although Fishacre's teacher, Robert Bacon (d. 1248), very probably lectured from the Sentences at some time during his career, there is no substantial evidence that he ever wrote a Commentary. Bale is the first to attribute a "Liber in sententias Petri Lombardi" to him, but this entry should not be taken too seriously. See F. Pelster, "Die Bedeutung der Sentenzenvorlesung für die theologische Spekulation des Mittelalters. Ein Zeugnis aus der ältesten Oxforder Dominikanerschule", Scholastik 2 (1927), 251, n. 3. See also n. 29 below.

2 B. Smalley, "Robert Bacon and the Early Dominican School at Oxford", Transactions of the Royal Historical Society (Fourth Series), 30 (1948), 20. Cf. Hugh of St. Cher's distinction between the "morales" and the "questioniste": Post. in Bibl. (Paris, 1530-45), 6, fol. 86. 
Prologue, the one pertaining to the speculative intellect, the other pertaining to the practical; the latter deals with moral instruction, the former with difficult points regarding the articles of faith. Although both parts are contained indistincte in Sacred Scripture, the magistri moderni treat them separately. The more difficult part has been excerpted from Scripture and placed in the book of the Sentences. ${ }^{3}$

Frater Richard's innovative approach did not, however, meet with immediate acceptance at Oxford.4 Indeed, the University's most influential and authoritative figure, Robert Grosseteste, had definitively opted for the older "unspecialized" theology. In $1246^{5}$ the Bishop of Lincoln had written to the regent masters at Oxford that the Old and New Testaments should be their only textbooks in theology and that courses on the latter be held in the morning hours, the time appointed for the "ordinary" lectures. Such was the custom of their fathers and elders; such also was the usage at Paris:

... hora est matutina qua ordinarie legitis; decet igitur vestras lectiones omnes, maxime tali tempore, legendas esse de libris Novi Testamenti vel Veteris; ne... a patrum et maiorum vestigiis et conformitate Regentium Parisius theologorum manifeste recedatur. ${ }^{6}$

So staunch, in fact, was Grosseteste's opposition that it appears to have occasioned a letter from the Pope. Between the years 1245 and 1247 an "epistola secreta" was issued from the court of Innocent IV, addressed to the Bishop of Lincoln, in which the Pope commands that "Frater R. de ordine Praedicatorum", presently teaching in the theology faculty at Oxford, be not prevented from lecturing ordinarie on the Sentences but rather that he be encouraged in every way:

${ }^{3}$ See below, pp. 96-7.

4 Although Fishacre's method ultimately prevailed, his contemporaries and immediate successors at Oxford - Adam Marsh, Simon of Hinton, Thomas Docking, and others - continued to tread firmly in the path of the "old theology" (Smalley, "Robert Bacon", 13). As late as 1267 Roger Bacon was still urging, even while acknowledging the passing of the old method, that all theological questiones be organically integrated with the interpretation of Sacred Scripture (Opus Minus, ed. J. S. Brewer, R. S. [London, 1859], 330). Bacon's "fourth sin of theology", in fact, was the exaggerated respect paid to the sententiarii (A. G. Little, "The Franciscan School at Oxford in the Thirteenth Century", Archivum Franciscanum Historicum, 19 (1926) 808. For this whole question and Fishacre's part in it see Smalley, The Study of the Bible in the Middle Ages, 2nd ed. (Notre Dame, Indiana, 1964), 279-80.

5 Both Luard and Thomson assign this date to the letter: R. Grosseteste, Epistolae, ed. H. R. Luard (London, 1861), 346; and S. H. Thomson, The Writings of Robert Grosseteste (Cambridge, 1940), 212. Cf. also Pelster, "Der älteste Sentenzenkommentar aus der Oxforder Franziskanerschule", Scholastik 1 (1926), 64.

6 Luard, p. 347. 
Mandamus quatenus dilectum filium fratrem R. de ordine Praedicatorum apud Oxoniam docentem in theologica facultate a lectione ordinaria libri Sententiarum non debeas prohibere, sed potius inducas eundem ut secundum gratiam sibi datam continentiam profundam et veritatem necessariam ipsius libri auditoribus aperiat studiosis, cum in eo catholicorum doctorum inveniantur testimonia fide digna quae depulsa erroris calligine tenendam fidelibus asserant veritatem.?

The "Frater R." of Innocent's letter is in all probability Richard Fishacre. ${ }^{8}$ His Sentence-Commentary certainly represents the kind of theological speculation commended by the Pope. Indeed, it does not seem unreasonable to see in the papal letter an attempt to defend the young Dominican against the imposing Bishop of Lincoln, who was undoubtedly acquainted with Fishacre's theological views, and who had quite contrary views of his own on the matter.

Although Innocent does not specifically mention Fishacre's Commentray, we may suppose that the work was in circulation by this time (i.e. 1245).$^{\circ}$ Pelster suggests the same date as a terminus ante quem, arguing from the fact that Fishacre does not cite Grosseteste's translation of the Nicomachean Ethics but utilizes rather the Ethica vetus. ${ }^{10}$ Now it is unthinkable, runs the argument, that Fishacre would not have used the new and superior translation; equally unthinkable is that he would have been unaware of Grosseteste's translation in view of the close contact the latter maintained with the Oxford masters. Since according to the best authority the new trans-

7 Padua, Bibl. Antoniana MS 79, fol. 50r. Sce G. Abate, "Lettere secretae d'Innocenzo IV e altri documenti in una raccolta inedita del saec. XIII", Miscellanea Franciscana (1955) 347, n. 149 for a description. Abate, however, wrongly gives the addressee as the bishop of London. C. A. B. Emden, A Biographical Register of the University of Oxford to A.D.1500, Vol. 2 (Oxford, 1957), 686.

8 Although the Dominicans were represented in Oxford at this time by Fishacre and Robert Bacon, the latter, as we have seen (n. 1 above), never wrote a Commentary. Moreover, since Bacon had incepted by 1219 (Smalley, "Robert Bacon", p. 1), it is probable that he would have surrendered the Dominicans' one chair in the theology faculty to his protégé by the 1240's. Hence the "ordinary" lectures would have been conducted by Fishacre during the period in question. Callus' remark is worth noting: "Unlike the secular masters... the friars' regency was generally limited to two or three years in order that others might in turn incept in theology. This was the custom of the Dominicans in Paris and of the Franciscans at Oxford and Cambridge; and we may be sure that the same system of promotion prevailed amongst the Oxford Dominicans", "The 'Tabulae super Originalia Patrum' of Robert Kilwardby O. P.", in Studia Mediaevalia in honorem R. F. Martin (Brugge, 1948), 251.

9 It is not unlikely - though there is no evidence at the moment to support this - that the Pope had seen a copy of the Commentary. At any rate Innocent's letter remains the earliest reference to Richard's academic activity.

10 "Das Leben und die Schriften des Oxforder Dominikanerslehrers Richard Fishacre (d. 1248)", Zeitschrift für katholische Theologie 54 (1930), 531. C.. Callus, Introduction, 32. 
lation was probably not circulated before $1246-47$, , we must place our Commentary before this date. ${ }^{12}$

That the work was written after 1241, on the other hand, is deduced from internal evidence. ${ }^{13}$ In book II, distinction 3, Fishacre refers to certain moderni who had incurred excommunication:

Novi multos modernorum magistrorum morulam cum Magistro hic ponere - in tantum etiam et quidam sententiam excommunicationis intulerint in illos qui suae potestati ordinariae subditos dixerint in eodem instanti creationis angelos peccasse et ceridisse. Sit igitur, si placet, pro ratione voluntas eorum et timeant, qui voluerint, excommunicationem, si non afferunt aliam rationem [italics mine]. ${ }^{\mathbf{1 4}}$

This is patently a reference to one of the propositions condemned at Paris by William of Auvergne on January 13, 1241:15

Quintus, quod malus angelus in principio sue creationis fuit malus, et numquam fuit nisi malus. Hunc errorem reprobamus, firmiter enim credimus, quod bonus creatus sit et post peccando factus sit malus. ${ }^{16}$

A tentative reconstruction of the sequence of events might run as follows: Fishacre's inception in theology, before 1240; his Commentary on the Sentences, c. 1241-45; Grosseteste's letter to the Oxford masters, 1246; Innocent IV's letter to Grosseteste, 1247.

11 Callus, "The Date of Grosseteste's Translations and Commentaries on Pseudo-Dionysius and the Nicomachean Ethics", Recherches de théologie ancienne et médiévale 14 (1947), 200-09; cf. ibid., "Robert Grosseteste as Scholar", in Robert Grosseteste, Scholar and Bishop, ed. Callus (Oxford, 1955), 64. Cf. also F. M. Powicke, Robert Grosseteste and the Nicomachean Ethics (London, 1930), 20. Pelster claims that Albert the Great utilized Grosseteste's Ethics in the last two books of his Sentence-Commentary shortly after 1246; "Das Leben", 531.

12 This line of reasoning is somewhat less than conclusive. Indeed, on the same premises we $\rightarrow$ should have to date our Commentary before 1242 - the terminus ante quem of Grosseteste's translation of Damascene's De fide orthodoxa - since Fishacre cites the older version of Burgundio of Pisa (see e.g. Oxford, Oriel Coll. MS 43, pp. cxirrb and ctxrb).

13 Some scholars still insist on an carlier dating: e.g. O. Lottin, Psychologie et morale aux XII' et XIII siècles (Louvain, 1949), II-2, 710 (viz. 1235-40); and J. Gründel, "Die Lèhre von den Umständen der Menschlichen Handlung im Mittelalter”, Beiträge 39, 5, p. 469.

14 Oxford, Oriel Coll. MS 43, p. xxvi. See the Introduction to Alexander of Hales, Glossa in Quatuor Libros Sententiarum, ed. Quaracchi (1951), I, 110*, n. 3.

15 One of the Fishacre manuscripts, in fact, contains the following marginal note: "Nota quod ita fuerunt magistri Parisienses; igitur (?) deficientes argumentis per excommunicationem arguunt opionem suam. Sed iste (?) modus arguendi est nimis practicus", London, B. M. Royal 10.B.VII, fol. "105v.

16 Chartularium Universitatis Parisiensis, ed. H. Denifle and E. Chatelain, Vol. 1 (Paris, 1889), 171. 


\section{The Manuscripts}

In preparing the first complete edition of Fishacre's Prologue, ${ }^{17}$ I have examined and collated the eleven manuscripts that are presently known to contain it.18 A twelfth manuscript, Cambridge, Trinity College MS 1054, contains portions of the Prologue under the rubric "Divisio scientiarum: quod accedentibus ad theologiam oportet alias praecognoscere"; $;$ 19 since it is only a fragment, however, it was not utilized in the present edition.

The following are the manuscripts and their sigla:

B - Oxford, Balliol College MS 57, fols. 1r-4r. ${ }^{20}$ This manuscript dates from the late 13th century and is of English origin; it is written in several good hands with small flourished capitals in red and blue. B is also one of only four complete manuscripts. It belongs to the family of $R$ and is closely related to the corrected version of $O$.

Bo - Bologna, Univ. MS 1546, cols. 1-6.21 Its small English script places this manuscript close to the middle of the 13th century; it contains only the first three books and has page, column, and (as far as p. 62) line numberings in fives. ${ }^{22}$ Bo once belonged to the Dominican convent of San Domenico in Bologna. ${ }^{23}$ It belongs to the family of $\mathbf{C}$.

\footnotetext{
17 Pelster published a fragment of the Prologue in Scholastik 2 (1927), 254-55, utilizing only the Oriel and Balliol College manuscripts.

18 Two additional manuscripts - Liverpool, Univ. MS F.4.18, and Naples, Naz. MS VII.C.19 - contain only book IV, which quite possibly circulated anonymously as a separate treatise De sacramentis. Fishacre himself sanctions such a division in his Prologue; sce below, p. 98. Cf. Thomas James' description of the Balliol College MS in his Ecloga Oxonio-Cantabrigiensis, Vol. 1 (London, 1600), 23 ( $\$ 51$ ). See also the handwritten inventory of the Vatican MS (below, n. 37), where the 4th book is entitled "Quedam Super Sacramenta".

Stegmüller also lists Brescia, Queriniana MS B VI 2 (Repertorium Commentariorum in Senientias Petri Lombardi, Vol. 1 [Würzburg, 1947], 348); the latter, however, was written not by Fishacre, nor by Bombolognus of Bologna (as Gründel, Beiträge 39, 5, 469), but by the anonymous author of Paris, Nat. lat. MS 14557, fols. 145-82, which contains bk. I, dists. 1-4 of a Sentence-Commentary.

19 The Trinity College manuscript contains a series of 71 questiones which have been excerpted from the first two books of Fishacre's Commentary and can be dated c. 1260. For a description see M. R. James, The Western MSS in the Library of Trinity College, Cambridge, Vol. 3 (Cambridge, 1902), 34-35.

20 For a complete description see R. A. B. Mynors, Catalogue of the Manuscripts of Balliol College Oxford (Oxford, 1963), 39-40; and Pelster, "Das Leben", 525.

21 See Pelster, "Das Leben", 526. The latter conjectures that G must have stood close to the original - mainly on account of its line numberings; see $n .22$ below. See also the description in L. Frati, Indice dei Codici Latini conservata nella $R$. Bibliotheca Universitaria di Bologna (Florence, 1909), 350. Frati, however, places the manuscript in the 14th century.

22 This custom of numbering lines in intervals of five seems to have been peculiar to a mid-thirteenth century Oxford scriptorium. The device was rare and serves to identify the earliest Fishacre manuscripts: viz. Bo, C, N, R, and V. Cf. Pelster, "Das Leben", 522-23.

${ }^{23}$ M.-H. Laurent, Fabio Vigili et les Bibliotheques de Bologne au début du XVI e siecle, Studi e Testi, 105 (Vatican City, 1943), 26. A note on the inside of the book cover reads: "Iste liber est provincie Lombardie concessus ad usum fratri Francisco Mant. (?) ordinis fratrum predicatorum".
} 
G - Cambridge, Gonville and Caius College MS 329/410, cols. 1-8.24 G also belongs to the mid-thirteenth century. It is complete, in several good hands, and its columns and lines are numbered as in Bo. Pelster suggests that $G$ might be a direct transcript from the original, with notes and corrections in the hand of Fishacre himself. 25

L - London, Lambeth Palace MS 116, fols. 123r-125v. ${ }^{26}$ This diversified manuscript, belonging to the 14th century, contains of Fishacre's work only the prologues to the four books of the Commentary. L's version of the Prologue edited below is quite corrupt and full of misreadings.

N - Oxford, New College MS 112, fols. 1r-11r. ${ }^{27}$ In a French hand this manuscript contains only the first two books. The lines are numbered as in Bo and G, and it appears to be a corrupted copy of the latter. Coxe places it at the end of the 13th century.

O-Oxford, Oriel Gollege MS 43 (B 4.3), pp. la-5b. ${ }^{28}$ It is a complete manuscript of English origin and can be dated towards the end of the 13th century. $O$ belongs to the family of $R$ and has been extensively corrected. A peculiarity of this manuscript is that the pages of each book are individually numbered. ${ }^{29}$

P - Paris, Bibl. Nat. lat. 15754, fols. $1 \mathrm{r}-2 \mathrm{r} .{ }^{30}$ The manuscript ends with bk. III, dist. 40. Its lines are numbered as in Bo, $C$, and $N$ up to fol. $36 \mathrm{v}$, but for the most part the numerals have been erased. It was bequeathed to the Sorbonne by the Paris master Gerard de Abbeville (d. 1271). ${ }^{31}$ We can date it as mid-13th century.

24 Described in M. R. James, A Descriptive Catalogue of the Manuscripts in the Library of Gonville and Caius College, Vol. 1 (Cambridge, 1907), 522.

25 "Das Leben", 522-23. In the bottom margin of col. 1002 (fol. 244r) there occurs the following note in the hand of the corrector: Albertus solvendo dicit econtrario, quod pena actualis venialis maior est quam originalis quia habet aliquid de voluntario, etc. If Pelster were correct in identifying the corrector as Fishacre, we would be presented with an interesting dating problem.

20 Described in James, A Descriptive Catalogue of the MSS in the Library of the Lambeth Palace (Cambridge, 1932), 189-92.

27 Described in H. O. Coxe, Catalogus Codicum MSS qui in Collegiis aulisgue Oxoniensibus, Vol. 1 (Oxford, 1852), 40; and Pelster, "Das Leben", 525. Callus states that $N$ is "very precious indeed, since it was transcribed during the author's lifetime while the work was still in progress, and ends at Book II" (Introduction, 32). He offers, however, no support for his allegation, and paleographic evidence as well as the corrupt state of the text would argue for a much later dating. It is possible that Callus had $\mathrm{S}$ in mind, on behalf of which a more solid case could be made for contemporaneity.

28 Described in Coxe, 16; and Pelster, "Das Leben", 524-25.

29 The flyleaf contains the following note: Fishacre super 1, 3, et 4 sententiarum. 'Qui fuit primus qui scripsit super sententias de ordine suo in Anglia, et jacet Oxonie inter fratres Predicatores; et constat iste liber collegio Sancte Marie, vocato Oryell... anno Christi $1430 . .$. - early evidence that Fishacre was the first Dominican at Oxford to write a Sentence-Commentary.

${ }^{30}$ Described in F. Ehrle, "L'Agostinismo e l'Aristotelismo nella Scolastica del Secolo XIII", Xenia Thomistica 3 (1925), 552-53; and Pelster, "Das Leben", 527-28. It was also mentioned by Echard in his Scriptores Ordinis Praedicatorum Recensiti, Vol. 1 (Paris, 1719), 118.

31 The back flyleaf contains this annotation: Iste liber est collegii pauperum magistrorum in theologica facultate studentium ex legato Magistri Gerardi de Abbirvilla (sic) pretii VIII lib. - and in a second hand: Vivebat 1265. 
R - London, British Museum MS Royal 10.B.VII, cols. 1-8. ${ }^{32}$ This manuscript, in several small hands, is complete; its lines are numbered as in Bo, C, N, and P.

On fol. Iv is a note (c. 1300): Iste fuit Fishaker fratris Galfridi de Willingham et est sub custodia prioris, referring probably to the Augustinian priory of St. Mary Overy, Southwark, the inscription of which, "Liber Beate Marie Ouerey", is on fol. $408 \mathrm{v}^{33} \mathrm{R}$ is heavily annotated, indicating classroom use. It can also be dated c. 1250.

S - Paris, Bibl. Nat. lat. 16389, fols. 1r-2v. ${ }^{34}$ Another Sorbonne manuscript, ${ }^{35}$ $\mathrm{S}$ ends with dist. 3 of bk. II. It is closely related to $\mathrm{V}$ and may even be a copy. On fol. $90 \mathrm{v}$ appears the following petition:

Rogo te lector, quisque es, ut roges Deum pro fratre Richardo de Fixacre, qui hoc opus edidit, ut eum Dominus nunc et semper in anima custodiat et in corpore vires prebeat, ut residuum operis ad finem prospere perducat. Amen:

The writer of these lines obviously believed Fishacre to be still alive; we may therefore tentatively date $S$ before $1248 .{ }^{36}$

V - Vatican, Ottob. lat. MS 294, fols. $1 \mathrm{r}-\mathrm{v}^{37}$ This manuscript, also of English origin, ends with bk. IV, dist. 8; its columns and lines are numbered as in Bo, G, etc. The script is quite small and more than usually abbreviated. It belongs to the family of $\mathbf{C}$ and is most closely related to $\mathrm{S}$. Ehrle places it in the 14 th century.38

Judging, however, from its script, its line numberings, and especially its affinity with S, I would date it close to $1250 .^{39}$

W - Vienna, Nationalbibliothek MS 1514, fols. 1r-3v.40 The manuscript, which clearly belongs to the 14 th century, contains only the first two books. It belongs to the family of $R$ but is very corrupt. The flyleaf has this note:

Ad Collegium Ducis. Scriptura et Compilatio bona super libros sententiarum quam felicis recordationis venerabilis olim M. Stephanus de Enczesdorff licentiatus in theologia canonicus Ecclesiae Sancti Stephani dicit pro libreria magistrorum. ${ }^{41}$

32 Described in G. F. Warner and J. P. Gilson, Catalogue of Western MSS in the Old Royal and King's Collection (B.M.) 1 (London, 1921), 313; and Pelster, "Das Leben", 525.

${ }^{33}$ Cf. Medieval Libraries of Great Britain: $A$ List of Surviving Books, ed. N. R. Ker, 2nd edition (London, 1964), 180.

34 Described in Ehrle, 553; and Pelster, "Das Leben", 528. It is also mentioned by Echard, 118.

85 This note occurs on the inside of the back cover: Iste liber est collegii magistrorum pauperum studentium in theologia pretium. XL fol.

36 See n. 27 above.

37 Described in Inventarium Codicum MSS Latinorum Bibliothecae Ottoboniae. Pars I, \#294; Ehrle, 553; and Pelster, "Das Leben", 526-27. It was first identified by A. Landgraf in Das Wesen der lässlichen Sünde in der Scholastik bis Thomas von Aquin (Bamberg, 1923), 105.

38 Ehrle, 553.

$39 \mathrm{~V}$ also contains two treatises, both very probably by Fishacre, that exist only in this codex: Adnotationes on Augustine's De haeresibus (fols. 287r-294v) and a quaestio on the ascension of Christ (fols. 294v-296r). I hope to publish these two pieces in the near future.

40 Described in Tabulae Codicum Manu Scriptorum in Bibliotheca Palatina Vindobonensi Asservatorum, ed. Academia Caesaria Vindobonensis, Vol. 1 (Vienna, 1864), 247; and Pelster, "Das Leben", 528. A. Daniels was the first to recognize this MS as being a copy of Fishacre's Commentary (in "Geschichte der Gottesbeweise in dreizehnten Jahrhundert", Beiträge 8, 1, p. 21).

41 An earlier catalogue identifies Magister Stephanus as head of the University (Vienna?) 


\section{The Edition}

Because no comparative study of the Fishacre manuscripts has yet been published, the apparatus variantium is designed to give a rather complete view of each of the eleven manuscripts that contain the Prologue. It was to this end that all of the latter were collated - including those that were obviously corrupt. ${ }^{42}$

Furthermore, although it would certainly be presumptuous to attempt to draw up a stemma codicum on the basis of the relatively limited piece I have collated, I can make a few tentative suggestions concerning the relationships among the manuscripts. These suggestions - and they are no more than that - might in turn serve as a working basis for future editions of the Commentary (or parts thereof).

There are, I submit, at least two distinct families: BORW and BoCNSV; let us refer to the first group as $\mathrm{X}$ and the second as $\mathrm{Y}$. $\mathrm{P}$ presents a problem; it is most closely allied with $S$ and $V$ (a sub-group of $Y$ ) and hence should probably be included in the $\mathrm{Y}$ family. On the other hand, there is a possibility that it represents a distinct tradition.

$\mathrm{R}$ appears to be the earliest exemplar of $\mathrm{X}$ and $\mathrm{G}$ the earliest of the $\mathrm{Y}$ family. Within these two groupings $I$ feel safe in adding only that $N$ displays a high incidence of variants in common with $\mathrm{C}$, and $\mathrm{S}$ with $\mathrm{V}$.

Although the manuscripts in the $\mathrm{Y}$ family are generally earlier than and superior to those in $\mathrm{X}, \mathrm{I}$ have for the most part followed the readings of $\mathrm{R}$ (of the $\mathrm{X}$ family). $\mathrm{R}$ is more correct - both in its grammar and its citations - than any of the $\mathrm{Y}$ manuscripts and it has fewer individual variants. A case can be made, moreover, for its early dating. I have felt free, however, to correct $\mathrm{R}$ in the face of substantial opposition or for the sake of completeness or obvious correctness; in short, my choice of $\mathrm{R}$ as codex optimus is at best probationary.

In noting variants, I have omitted those of a purely orthographic nature, except in a few cases where a misreading on the part of the scribe seemed to be in evidence. I have noted such obviously mechanical copying errors as dittography, haplography, and homoeoteleuton. Only occasionally, however, have I recorded corrections, deletions, and additions (in a later hand) in the individual manuscripts; nor did I think it necessary or practical to record variations in word order.

in 1391; Codices Manuscripti Theologici Bib. Palatinae Vindobonensis Latini, recensuit M. Denis, Vol. 2, Pars II (Vienna, 1800), col. 1228. The compiler of the catalogue asserts not only that it would be difficult to identify the author of the manuscript "O altitudo..." from among "such a great crowd of commentators" but also that it would not even be worth the trouble (ibid., col. 1229).

42 I have in mind especially $L_{4}, N_{2}$ and $W$; these MSS might well be passed over in an eventual edition of the entire Commentary. 
The punctuation of the text follows the canons of modern English, and the orthography has been standardized, with the exception of the long-i which is retained as " $\mathrm{i}$ ". I have also made an attempt to search out all the sources, which are listed separately according to letter.

I wish to acknowledge my gratitude to the Fulbright Commission and The Canada Council for grants enabling me to examine personally all of the manuscripts utilized below, as well as to Fairfield University for a grant covering the preparation of the manuscript.

\section{RICHARD FISHACRE, COMMENTARIUM IN LIBROS SENTENTIARUM PROLOGUS}

Ro. XI: "O altitudo divitiarum sapientiae et scientiae Dei". ${ }^{12}$ Constat non est parum admirabilis illa sapientia quam admirans sic exclamat Doctor Gentium, qui raptus usque ad tertium caelum "audivit archana verba quae non licet homini loqui", Cor. 12.2b

Propterea videamus quae sit $^{3}$ ista. Duplicem dicit Iacobus in canonica sua $^{4} 3$, in fine, ${ }^{5}$ esse sapientiam unam quidem ${ }^{6}$ desursum, $^{c}$ et $^{7}$ aliam de ${ }^{8}$ deorsum quae complectitur omnes saeculares scientias. Quam idem ibi$\mathrm{dem}^{9}$ in tres partes dividit dicens: "Non est ista sapientia desursum descendens, sed terrena ${ }_{3}$ animalis, et diabolica". " Terrena quantum ad lucrativas $^{10}$ scientias; ;1 animalis quantum ad physicas; diabolica quantum ad haereticas et magicas sub quibus continentur quaedam astrorum iudicia, geomantia, et omnes divinationes, et ${ }^{12}$ auguria, et sortilegia. Quia ergo istae $^{13}$ omnes de ${ }^{14}$ deorsum sunt, constat quod nulla earum ${ }^{15}$ est illa ${ }^{16}$ cuius altitudinem admiratur Apostolus sic exclamans, $O$ altitudo, et cetera, ${ }^{\circ}$

1 add. et cetera $L$.

om. W.

3 add. sapientia $P$.

add. capitulo SV.

5 om. in fine SV.

- quid W.

7 om. S.

8 om. BCN; i.m. PS.

a Romans 11: 33.

b II Corinthians 12: 4.

c James 3: 15 .

d Ibid.

e Romans 11: 33.
9 ibi SV; om. P.

10 om. lucrativas... animalis quantum at $\mathrm{L}$.

II terrenorum BORSVW; add. terrenorum P.

12 om. P.

13 illae $O$.

14 om. BNW.

15 illarum L.

10 add. de W. 
sed illa tantum quae desursum est. Unde, manifestans cuius altitudinem admiretur, subdit sapientiae et scientiae Dei, quasi dicat non mundi, id est saecularium scientiarum.

Illas ergo relinquimus; ${ }^{17}$ de hac sola intendimus. Haec autem tripliciter ${ }^{18}$ est, quasi in triplici libro scripta: scilicet in libro vitae, in libro Scripturae, ${ }_{2}^{19}$ in libro creaturae. Unde Prov. 22: "Ostendam tibi eam ${ }^{20}$ hodie", 1 id est in praesenti tempore. Ecce descripsi eam tibi ${ }^{21}$ tripliciter. De hac ergo non ut scripta est in mente divina, nec ut scripta est in creatura, sed secundum quod scripta est in $^{22}$ sacra Scriptura intendimus. $\operatorname{In}^{23}$ libro enim vitae legunt beati spiritus in caelo. In libro creaturae legit Adam ante peccatum in paradiso. In libro vero Scripturae legendum nobis est in hoc exilio. De hac ergo quae desursum est sapientia secundum quod scripta ${ }^{24}$ est in sacra Scriptura intendimus.

De qua quattuor videamus secundum quattuor genera causarum, scilicet necessitatem vel utilitatem quod ${ }^{25}$ spectat ad causam finalem, auctorem ${ }^{26}$ quod spectat ad ${ }^{27}$ efficientem, subiectum quod spectat $\mathrm{ad}^{28}$ causam ${ }^{29}$ materialem, unitatem et divisionem quod spectat ad causam formalem. Quod autem sit non tantum utilis sed necessaria sic potest constare. ${ }^{30}$ Innatum est homini desiderium sciendi non tantum hoc vel illud sed omnia. ${ }^{31}$ Unde ${ }^{32}$ philosophus Aristoteles: ${ }^{33}$ "Omnis homo natura scire desiderat".g Non dixit scire hoc vel illud sed $^{34}$ simpliciter, dans intelligere desiderium sciendi omnia esse nobis innatum. Unde Luc. 18, in ${ }^{35}$ fine, caeco ${ }^{\text {h }}$ qui figurat humanum genus. In persona enim humani generis $\operatorname{dicit}^{36}$ Ps.: "Lumen oculorum meorum et ipsum non est mecum". ${ }_{1}$ Dicit Dominus: "Quid" vis ut faciam tibi? At ${ }^{38}$ ille dixit: Domine ut videam".j Non dicit

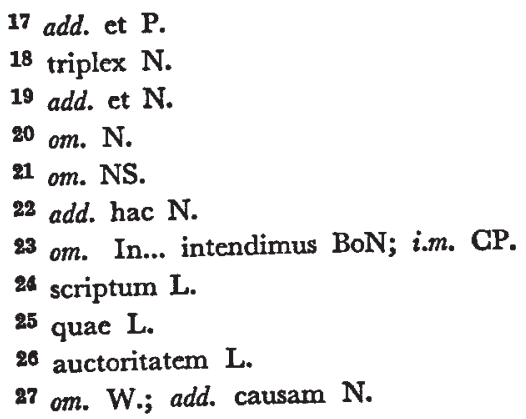

j Luke 18: 41 .
28 om. W.

29 om. N.

30 constatere (sic) L.

31 simpliciter B.

32 om. unde... Aristoteles B.

33 om. NV; add. (i.m.) in principio Meth. veteris P.

34 add. scire $\mathbf{R}$.

35 om. in fine BoCN.

${ }^{36}$ dixit N.

37 om. L.

38 ad L; et $O$. 
"Omnia vidit oculus meus ${ }^{64}$ et audivit auris mea, et intellexi"..5 q $\mathrm{Ad}$ hoc enim ut occulta sufficienter fiant manifesta, exigitur doctrina audibilis et ${ }^{68}$ exemplum visibile. Sic ut occulta caelorum et stellarum innotescant, scilicet motus et quantitates, fiunt ${ }^{67}$ quaedam exempla caelorum visibilia et $^{68}$ totius mundialis machinae. ${ }^{69}$ Scribitur etiam doctrina audibilis docens ${ }^{70}$ quid in exemplo cui conveniat in caelo.

Sicut ergo sapientia astrorum tota quidem est.in corporibus caelestibus excellentissime sed ibi nos latet; tota insuper in scriptura, ut forte in ${ }^{71}$ Almagest Ptolemaei; ${ }^{\mathbf{r}}$ tota insuper ${ }^{22}$ instrumentis ligneis tamquam in exemplo, et ibi quidem ignobilissime. Et scriptura quidem et exempla illa non sunt nisi ad manifestandum illam quae est in corporibus caelestibus: exempla quidem per visum, scriptura ${ }^{73}$ per auditum.

Sic ista ${ }^{74}$ quidem sapientia omnium principaliter et excellentissime est in libro vitae. Sed ibi ratione dicta nos latet. Est et ${ }^{75}$ tota in Scriptura sacra et tota in universa creatura; et utraque harum necessaria est ad manifestationem illius in libro vitae: Scriptura quidem ${ }^{76}$ per auditum, et universitas

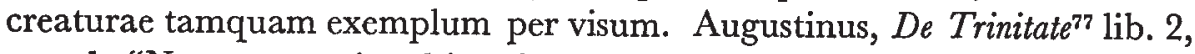
cap. 1: "Non ero segnis ad inquirendum substantiam Dei, sive per scripturam eius, sive per creaturam. Quae utraque nobis ad hoc proponuntur intuenda, ut ipse quaeratur, ipse diligatur, qui et illam inspiravit; et istam creavit".s $\mathrm{Et}^{78}$ haec sapientia sicut in libro vitae est nobilissima, sic in libro creaturae ${ }^{i 9}$ ignobilissima, et in sacra Scriptura medio modo.

Sicut ergo dicit Astrologus: caelum movetur ab oriente in occidentem ${ }^{80}$ super duos polos, quorum unus est ${ }^{81}$ punctus austri, et ${ }^{82}$ alter septentrionis,

64 om. L.

65 add. singula N.

66 et exemplum: texemplum (sic) L.

${ }^{67}$ fuerit $\mathrm{W}$.

68 ut L.

69 animae $\mathrm{L}$.

70 docens quid in exemplo: dicens in exemplo quidem quid $\mathbf{N}$.

71 om. R.

72 add. in LNRV.

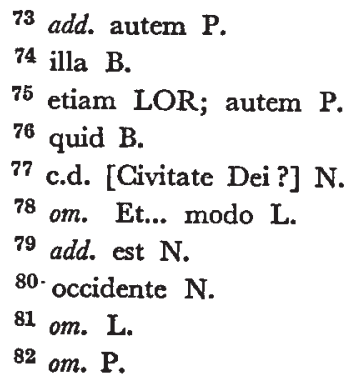

q $70 b$ 13: 1 .

I Fishacre was probably acquainted with Gerard of Cremona's translation of the Almagest (or the Syntaxis mathematica) from the Arabic. Delambre reports the existence of an Arabic-Latin MS of the Almagest at Oxford in 1230; Ptolemaeus, Composition mathématique, tr. M. Delambre (Paris, 1927), p. xxxIx.

Augustine, De Trinitate II, proem.; PL 42. 845. 
sicut $^{83}$ vides in hac sphaera lignea. ${ }^{t}$ Sic dicit Theologus: Deus est trinus et unus, sicut vides in igne, qui unus est, tria tamen ${ }^{84}$ in se habens, ${ }^{85}$ calorem $^{86}$ scilicet et lucem et splendorem. ${ }^{u}$ Sicut ergo non sciuntur occulta astrorum ${ }^{87}$ per exempla sine scriptura, sic nec sapientia haec ${ }^{88}$ in mente divina cognoscetur per universitatem ${ }^{89}$ creaturarum sine sacra Scriptura. Et ideo in libro creaturae tantum ${ }^{90}$ studentes physici nec mirum erraverunt, nescientes quid ${ }^{91}$ in creatura cuius esset exemplum in Creatore. Sic ergo patet sacrae Scripturae necessitas.

Ex eisdem etiam ${ }^{92}$ potest patere eius ${ }^{93}$ sublimitas. Est enim sublimis vel alta dupliciter, ${ }^{94}$ scilicet sicut dicitur caelum altum, et sicut dicitur puteus altus, id est profunda et $^{95}$ alta; et utrumque quidem ad altitudinem facit. Quod enim est profundum existenti sursum, ${ }^{96}$ hoc est altum existenti deorsum.

Sicut enim iam dictum est: in ipsa ${ }^{97}$ sunt omnia quaecumque sunt in mente divina. Sed ${ }^{98}$ in mente divina sunt omnia. Ergo et ${ }^{99}$ in ea. Cui ${ }^{1}$ attestatur $^{2}$ Augustinus in libro 2 De Doctrina Christiana, dicens omnem ${ }^{3}$ veritatem in ea reperiri his verbis: "Quantum minor" est auri, ${ }^{5}$ argenti vestisque copia, quam de Aegypto secum ille populus abstulit, ${ }^{6}$ in comparatione divitiarum quas postea Ierosolymae consecutus est, quae maxime in Salomone rege ostenduntur; tanta fit $^{7}$ cuncta scientia quae quidem utilis est, collecta de libris gentilium, ${ }^{8}$ si divinarum Scripturarum ${ }^{9}$ scientiae comparetur. Nam quicquid homo extra didicerit, ${ }^{10}$ si noxium est, ibi damnatur;

83 sic BoSV.

84 om. tamen... habens $\mathrm{N}$.

85 add. quia $\mathrm{G}$; add. scilicet BoV.

86 calorem sc. et lucern et splendorem: calorem, lucem et splendorem BoCSV; calorem sc. lucem et splendorem PW; calor sc., lux et splendor $\mathrm{N}$.

87 add. et $\mathrm{N}$.

88 hic BW; om. N.

89 numerositatem $N$.

90 tăg (?) W.

91 quod B; quidem $\mathrm{N}$.

92 autem $O$.

93 cuius L.

94 duplex L.

95 vel L.

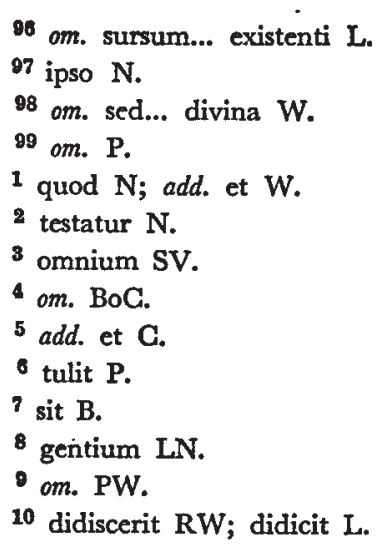

t This seems not to be a derbatim quote, but rather a loose reference to Ptolemy's Syntaxis mathematica A, cap. y; ed. J. Heiberg, I (Leipzig, 1898), 10-11. G. Grosseteste's De sphaera in Beiträge IX, 10-14.

u Cf. Pseudo-Augustine, De Symbolo III, 9; $P L$ 40. 659. This sermon was actually composed by Quodvultdeus (d. 453); cf. Clavis Pat. Lat., 2nd ed. (1961), p. 99, 403. 
exclamet: ${ }^{34}$ "O altitudo divitiarum sapientiae et ${ }^{35}$ scientiae Dei". d Quae quidem sapientia dicitur in quantum loquitur de supremis; scientia vero in quantum exemplificat de infimis. Sapientia est cum dicit: Deus trinus et unus est; scientia est ${ }^{36}$ cum subdit: sicut unus ignis tria habet in se. $^{37}$

Hinc statim patet quod omnes aliae scientiae sunt huius ${ }^{38}$ pedisequae et ancillae. Cum enim ${ }^{39}$ singulae sint de singulis universi partibus, totum autem universum se habet ad hanc, sicut exemplum ad scientiam cuius est exemplum. Patet quod omnes aliae laborant ad declarationem exemplorum huius scientiae.

Hinc insuper ${ }^{40}$ patet quod accedentem ad hanc oportet alias praecognoscere vel. universaliter omnes vel pro magna parte; alioquin ignorabit exempla huius scientiae. Non enim aggreditur ${ }^{42}$ quis ad hanc dominam, maxime ad secretum cubiculi ${ }^{43}$ eius, $^{44}$ nisi prius familiaris fiat ancillis ${ }^{45}$ hostiariis quae eum introducant. Unde Gal. 4: "Abraham duos filios habuit, unum de ancilla, et alterum de libera". e Nota ${ }^{46}$ quod prius de ancilla, ${ }^{47}$ postea de libera, sicut scribitur Gen. 16. Quod ${ }^{48}$ si aliquis $^{49}$ quasi furtim ${ }^{50}$ intrans ad dominam non allocutus ancillas, vi conatur eam opprimere. Quamvis quidem eam vi cognoverit, tamen generare non poterit, id est docere. Quod bene figuratur ${ }^{51}$ ibidem, scilicet $^{52}$ Gen. 16, ${ }^{1}$ ubi legitur Abraham non potuisse gignere filios de Sarai, quae princeps vel domina interpretatur, quamvis eam cognovisset antequam cognovisset ancillam eius Agar, quae significat saeculares scientias. Unde Bar. 3: "Filii Agar, qui exquisierunt prudentiam ${ }^{53}$ quae de terra est". ${ }^{54 g}$

Sic ergo tibi ${ }^{55}$ cuilibet ignoranti alias scientias, dicit haec scientia quod Sarai dixit Abrahae Gen. 16: "Ecce, conclusit me Dominus, ne parerem. Ingredere ad ancillam meam, si forte saltem ex ea suscipiam liberos".
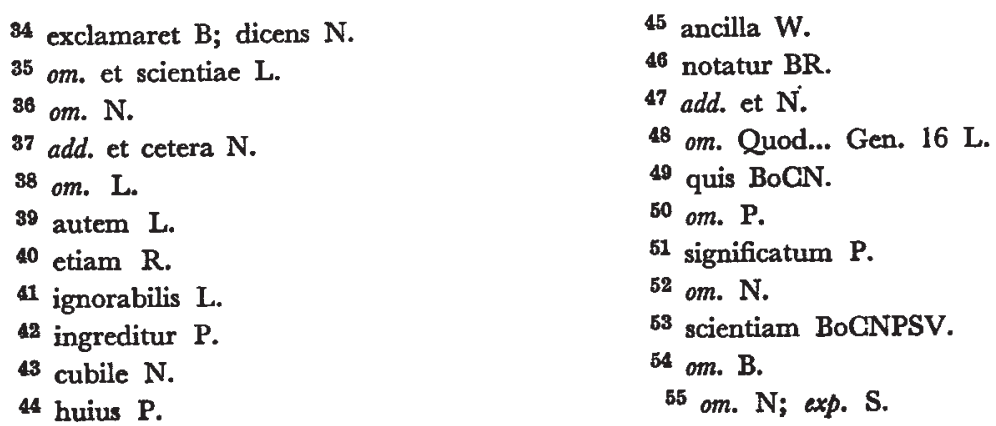

d Romans 11: 33.

e Galatians 4: 22.

$f$ Genesis 16: 14 .

g Baruch 3: 23. 
Et statim sequitur: "Cumque ille adquievisset deprecanti, tulit Agar aegyptiam ancillam suam, post annos X quam habitare coeperant". " Hoc idem significatum est Gen. 30, ubi legitur Iacob non potuisse generare de Rachel, nisi postquam ${ }^{56}$ genuit filios de eius ancilla. Unde ibi scribitur: "Cernens Rachel quod infecunda esset, Habeo, inquit, famulam Balam; ingredere ad illam ${ }^{57}$ ut pariat super genua mea, ${ }^{58}$ et habeam ex ea filios". ${ }^{1}$ Rachel ${ }^{59}$ interpretatur videns principium, Bala inveterata vel absorbens.

Sed fateor mirabile est de quibusdam hodie ${ }^{60}$ qui tantum delectantur in amplexibus vilis pedisequae, quod nonl curant de domina, quamvis sit inaestimabilis pulchritudinis, sicut de hac scientia" dicitur Sap. 7: "Est' enim haec speciosior sole, et super omnem ${ }^{63}$ stellarum dispositionem luci comparata, prior invenitur".I Ideo ante in eodem capitulo de ea dicit sapiens: "Super salutem et omnem speciem dilexi64 eam". ${ }^{6}$ Sap. 8:65 "Hanc amavi, et exquisivi eam a iuventute mea, et quaesivi sponsam eam assumere mihi, et amator factus sum formae illius". 1 Hi sunt qui vix cum caligant oculi a saecularibus scientiis, hoc est a sinu ancillarum avelluntur, ${ }^{66}$ et tunc se amplexibus dominae offerunt, $\mathbf{c u m}^{67}$ prae senectute generare nequeunt. ${ }^{68}$

Sic David ${ }^{69}$ iam senex dormivit cum pulcherrima Abisag; ${ }^{70}$ Reg. $3,{ }^{71}$ in principio.m Sed "non"2 cognovit eam", sicut ibidem dicitur." Sic procul dubio nec ${ }^{73}$ tales theologiam cognoscent ${ }^{74}$ qui usque ad senectutem alias scientias nimis ${ }^{75}$ scrutantur. ${ }^{76}$ Heb. 5: "Cum deberetis magistri esse

56 priusquam BoC.

57 eam BoCN.

58 ra (sic) W.

59 om. Rachel... absorbens BORW: i.m. L.

60 hominibus BoCNS; add. hominibus $P$.

61 sapientia BoCSV; om. N.

62 om. est enim $\mathrm{N}$.

63 om. N; omnium BoC.

64 om. I.

$656 \mathrm{~N}$.

66 evelluntur BoCNPSV.
67 et S.

68 inqueunt $W$.

69 add. est L.

$70 \mathrm{ab}$ isaac NO.

71 om. BBoLRV; i.m. II Reg. S.; 3 in principio: $1 \mathrm{~N}$.

72 om. R.

73 non B.

74 cognoscunt N; cognoscens L.

75 om. BoCNPS.

76 scrutentur S.

h Genesis 16: 2-4.

i Ibid. 30: 1-3.

j Wisdom 7: 29.

k Ibid. 7: 10 .

1 Ibid. 8: 2.

m"Et rex David senuerat, habebatque aetatis plurimos dies... invenerunt Abisag Sunamitidem, et adduxerunt eam ad regem. Erat autem puella pulchra nimis, dormiebatque cum rege, et ministrabat ei; rex vero non cognovit eam", III Kings 1: 1-4.

n Ibid. 1: 4. 
propter tempus, rursum indigetis ut $\operatorname{vos}^{77}$ doceamini quae sunt ${ }^{78}$ elementa exordii sermonum Dei". ${ }^{\circ}$ Ideo dicitur" ${ }^{79}$ Eclus. 41: "Ne ${ }^{80}$ scruteris ancillam eius", p scilicet nimis diu immorando. Quod si nimis scrutaris ancillas, deficies a domina. Ps.: "Defecerunt scrutantes scrutinio".q Abisag" id est patris mei tonitruum $\mathbf{r}$ - significat sacram Scripturam in qua comminando, non percutiendo, paterno affectu tonat Deus. Unde Ps.: "Vox tonitrui tui" id ${ }^{82}$ est comminationis tuae ${ }^{83}$ "in rota", legitur ${ }^{84}$ in ${ }^{85}$ Ezec. in principio: quod ${ }^{86}$ ambulabat $^{87}$ iuxta 4 animalia, ${ }^{t}$ quae - ut patet ibi - significat ${ }^{88}$ sacram Scripturam.

Sed quis potest esse auctor huius Scripturae ${ }^{89}$ vel sapientiae? Constat quod $^{90}$ Deus vel ${ }^{91}$ angelus. Non ${ }^{92}$ enim aliqua ${ }^{93}$ sed omnis veritas est in ea, ut dictum est. Ergo ab homine nec ${ }^{94}$ dicta nec scripta est. Ut enim dicit Ps.: "Omnis homo mendax". " Et Ecclus. 34: "A mendace quid verum dicetur" ?v quasi dicat nihil. Ergo multo magis omnis veritas ab homine, dico puro, dicta non est. Immo nec homo nec angelus. Veritates ${ }^{95}$ enim infinitae sunt, quia ${ }^{96}$ numeri ${ }^{97}$ et figurae infiniti ${ }^{98}$ sunt, de quorum quolibet multa sunt vera. Sed ${ }^{99}$ omnis veritas in ea est. Ergo infinitae veritates in ea sunt.

Sed $^{1}$ si linguis hominum loquar et angelorum, ${ }^{\mathrm{w}}$ non sufficiam dicere infinita, quia sum² finitae potentiae. Ergo nec homo nec angelus, immo nec

77 om. L.

78 sint $\mathrm{S}$.

79 dicit $B$.

80 non $P$.

81 ab isaac $\mathrm{N}$.

82 om. id... tuae B.

83 om. RW; tui L.

84 om. legitur in $\mathrm{N}$.

85 om. BoCP.

86 quae BoCNP; qui $S$.

87 ambulat $\mathrm{N}$.

88 significant $\mathrm{B}$.

89 scientiae BoCNSV.
90 om. P.

91 et $\mathrm{N}$.

92 add. est $N$.

93 alia L.

94 non L.

95 veritas $B$.

96 om. quia... sunt $\mathrm{L}$.

97 numerus $\mathrm{N}$.

98 infinitae $N$.

99 si ergo $\mathrm{N}$.

1 i.m. Cor. $13 \mathrm{C}$.

2 sum finitae: sunt infinitae B; sunt (m. post.) finitae $\mathrm{N}$.

- Hebrews 5: 12.

p Ecclesiasticus 41: 27.

q Psalms 63: 7.

r Cf. Jerome: "Abisag, pater meus superfluus, sive patris mei rugitus", De nominibus hebraicis, de Reg. III; PL 23. 863.

s Psalms 76: 19.

t "Cumque ambularent animalia, ambulabant pariter et rotae iuxta ea", Ezechiel 1: 19.

u Psalms 115: 11.

v Ecclesiasticus 34: 4.

w Gf. I. Corinthians 13: 1. 
homo et $^{3}$ angelus, nisi virtute alicuius qui ${ }^{4}$ est virtutis infinitae - quod $^{5}$ convenit soli Deo. Huius auctor esse potest. Ergo Deus huius ${ }^{6}$ est auctor.

Item quod non potest minus, ${ }^{7}$ non potest maius. Sed maius est et nobilius universitas omnium secundum quod est in libro Scripturae quam secundum quod est in libro creaturae. Sic enim proprie habet esse in anima; illo autem modo in materia. Multo autem est inferior et ignobilior materia quam rationalis anima. Ergo cum nulla creatura potuerit ${ }^{8}$ scribere omnia in ma-

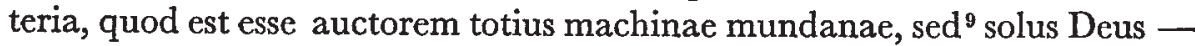
unde Gen. 110: "In principio creavit Deus caelum et terram"11x - multo12 fortius nulla poterat ${ }^{13}$ esse auctor sacrae Scripturae, sed solus Deus. Licet ergo aliquid sacrae Scripturae videatur Moyses scripsisse, aliquid similiter prophetae, aliquid ${ }^{14}$ evangelistae, aliquid apostoli, tamen non ipsi, sed Deus per $\operatorname{eos}^{15}$ et scripsit et locutus est ${ }^{16}$ tamquam principalis efficiens per instrumentum. Unde Psalmus non se scriptorem sed calamum scriptoris dicit. "Lingua mea", inquit, "calamus scribae". ${ }^{17 y}$ Et ideo dicit"18 Reg. 2319: "Spiritus Domini locutus est per me, et sermo eius per linguam meam". z Et ideo dicit Christus, Matt. 10: "Non"20 vos estis qui loquimini, sed Spiritus Patris vestri21 qui loquitur in vobis".

Hinc patent tria, scilicet quod haec ${ }^{22}$ est perfectissima, ${ }^{23}$ ordinatissima, et certissima. ${ }^{24}$ Perfectissima quia eius auctor ${ }^{25}$ Deus; sed ${ }^{26}$ Deu. 32: "Dei perfecta sunt opera". b Item si in ea est omnis veritas: sed omne totum et perfectum idem sunt; ergo est perfecta. Item omni ${ }^{27}$ veritati non est ${ }^{28}$ possibilis additio. Sed in ea est omnis veritas. Ergo ei non est possibilis additio.

3 nec $P$.

4 quod BoCP; om. qui est N.

5 quae N.

6 add. scientiae $\mathrm{N}$.

7 minus non potest maius: maius nec minus $\mathrm{G}$; maius non potest minus BoNO.

${ }^{8}$ potuit $\mathrm{G}_{\text {; }}$ possit $\mathrm{OP}$.

om. W.

10 om. N.

11 add. ergo $\mathrm{B}$.

12 om. multo... poterat $W$.

13 poterit CNP.

14 om. $\mathrm{P}$.

15 ipsos L.

$x$ Genesis 1: 1.

y Psalms 44: 2.

z II Kings 23: 2.

a Matthew 10: 20.

b Deuteronomy 32: 4.
16 add. per eos L.

17 scribac: velociter scribentis $O$.

18 dicitur N.

$19323 \mathrm{~N}$.

20 om. W.

21 om. BoCPSV.

22 om. haec est $\mathrm{N}$.

23 add. et $P$.

24 add. est haec scientia N.

25 add. est $\mathrm{P}$.

26 om. N.

$27 \mathrm{om}$. W

28 om. C. 
Sed perfectum est cui non est possibilis additio. Ergo ipsa est perfecta. Et ideo in $^{29}$ ipsa nihil ${ }^{30}$ superfluum, nihil ${ }^{31}$ diminutum. Unde Deu. 4: "Non addetis aliquid verbis quod" vobis loquor, ${ }^{33}$ nec auferetis ex ${ }^{34}$ eo".c Eccles. 3: "Non possumus eis ${ }^{35}$ quicquam addere, nec auferre, quae fecit Deus".d Ecclus. 18: "Non est minuere, ${ }^{36}$ neque adiicere". " Apoc. 22: "Si quis aposuerit ad haec, apponet ${ }^{37}$ Deus super illum plagas scriptas quae sunt in libro isto. Et si quis diminuerit ${ }^{38}$ de verbis prophetiae libri huius, auferet ${ }^{39}$ Deus partem eius de libro vitae".

Ordinatissima est, quia Deum habet auctorem. Ro. 13: "Quae autem a Deo sunt, ordinata sunt".g

Certissima ${ }^{40}$ quia auctor est Deus. Sed ${ }^{41}$ Ro. 3: "Deus autem verax est"." Immo veritas: Io. $14 .{ }^{421}$ Ergo $^{43}$ nec falli potest, nec fallere vult..4

Hinc patet quod minimum et incertissimum huius Scripturae verbum certius est conclusione certissimae demonstrationis. Quamvis enim demonstratio fallere non novit, nos ${ }^{45}$ tamen, quia homines sumus, falli possumus credendo esse demonstrationem quod non est demonstratio. Et ideo ad hoc ut certissime sciremus illam ${ }^{46}$ conclusionem, exigeretur non tantum ut demonstraretur per ${ }^{47}$ demonstrationem, sed etiam ut demonstraretur illam demonstrationem esse ${ }^{48}$ demonstrationem; quod non posset fieri sine aliqua $^{49}$ demonstratione; quam esse demonstrationem iterum ${ }^{50}$ demonstrare ${ }^{51}$ oporteret. Unde Philosophus: ${ }^{52}$ Discentem credere oportet. ${ }^{53 j}$ Ergo quia

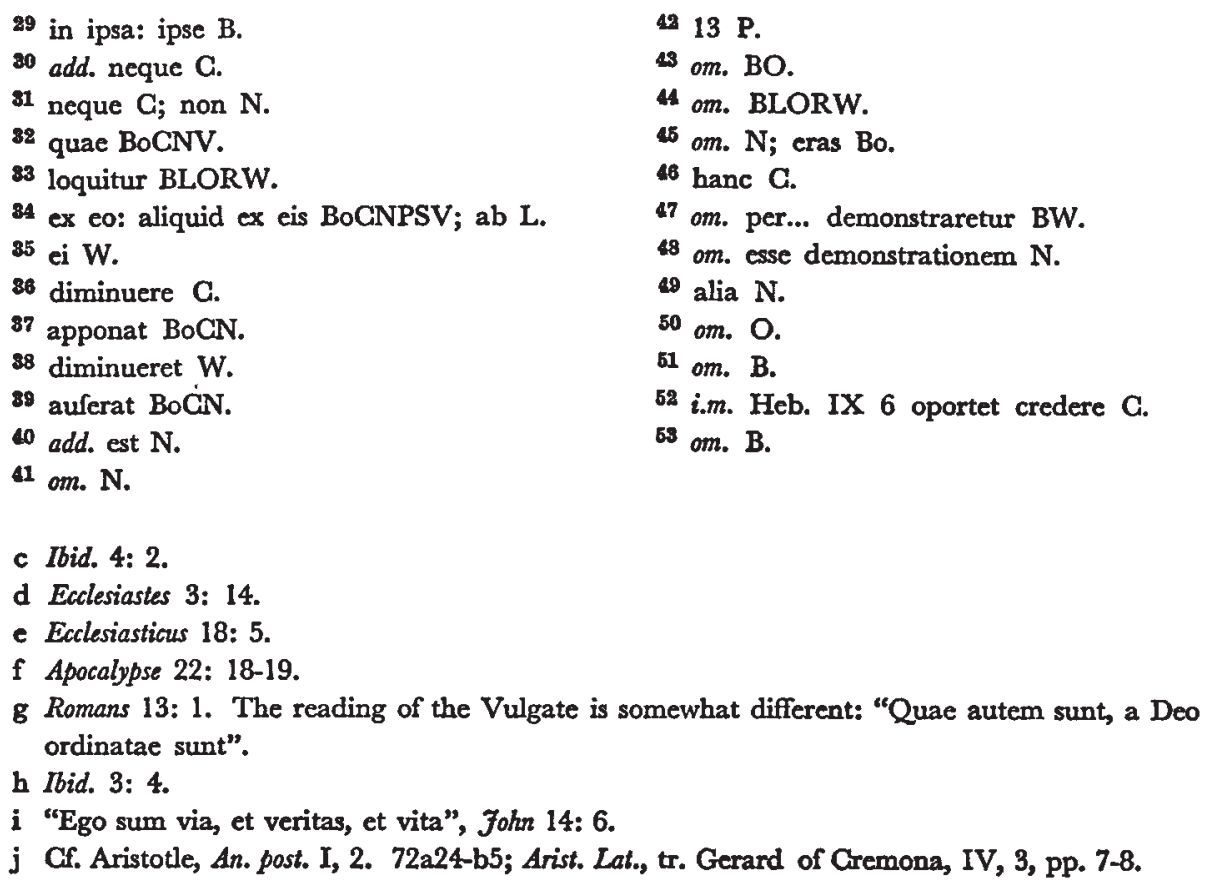

$4213 \mathrm{P}$.

43 om. BO.

4 om. BLORW.

45 om. N; eras Bo.

46 hanc $\mathrm{C}$.

$\$ 7$ om. per... demonstraretur BW.

48 om. esse demonstrationem N.

40 alia N.

50 om. $\mathrm{O}$.

51 om. B.

52 i.m. Heb. IX 6 oportet credere G.

63 om. B. 
scimus quod decipi possumus credendo esse demonstrationem quod non est, $^{54}$ patet quod ${ }^{55}$ nihil demonstratione ${ }^{56}$ potest fieri nobis tam certum quam $^{57}$ certum est illud nobis quod Deus dixit. De quo constat quod nec fallere vult, nec falli potest.

Item vis vel ${ }^{58}$ virtus demonstrationis certitudinem facit conclusionis. Sed $^{59}$ in infinitum maior est virtus Creatoris. Quomodo ergo non certius erit eius verbum qualibet conclusione? Credimus conclusioni quam confirmat medium demonstratum quod utique creatura est; et non credemus ${ }^{60}$ sermoni quem confirmat Creator omnis creaturae. Maior ergo et certior est auctoritas huius Scripturae qualibet demonstratione. Unde Augustinus, Super Genesim ad Litteram lib. 2: "Maior est Scripturae huius auctoritas, quam omnis humani ingenii' ${ }^{61}$ capacitas". ${ }^{\mathrm{k}}$

Hinc patet quod haec ${ }^{62}$ scientia vel Scriptura non est demonstrativa, nec $^{63}$ decurrit a praemissis ${ }^{64}$ ad conclusionem. Non enim ut dictum est innititur rationi sed scriptoris auctoritati. Et cum maioris certitudinis sit auctoritas huius Scripturae quam omnis demonstratio, probare aliquid ${ }^{65}$ scriptum in ea est ac si propositio aliqua optime demonstrata ratione probaretur dialectica ${ }^{66}$ vel sophistica, ut certior fieret.

Item cum sufficiens certificatio ${ }^{67}$ omnium hic scriptorum sit auctoritas ${ }^{68}$ scribentis, patet omnia esse aeque certa. ${ }^{69}$ Demonstratio autem procedit ex magis notis ad minus nota. Ergo haec non debet esse demonstrativa.

Quia ergo hanc scripsit Veritas, nihil est in ea falsitatis, quia Via nihil ${ }^{70}$ erroris, quia Vita nihil contrarium saluti. Quod si tantus est huius sapientiae Auctor, quales debent esse auditores! Utique qui vult veritates istas cognoscere, oportet verum discipulum esse. Unde $I s$. 8: "Signa" legem in discipulis meis". ${ }^{721} \mathrm{Et}^{73}$ Io. 8: "Vere discipuli mei eritis, ${ }^{74}$ et cognoscetis veritatem", sed non infructuose; sequitur enim, ${ }^{75}$ "et veritas liberabit vos".m

\footnotetext{
54 add. demonstratio $L$.

65 quia B.

56 demonstrare L.

57 om. quam certum W.

58 aut $\mathrm{N}$.

59 sed in infinitum (bis) C.

o0 credimus NS.

61 generis L.

62 om. W.

63 om. nec... maioris $W$.

04 add. usque $\mathrm{N}$.
}

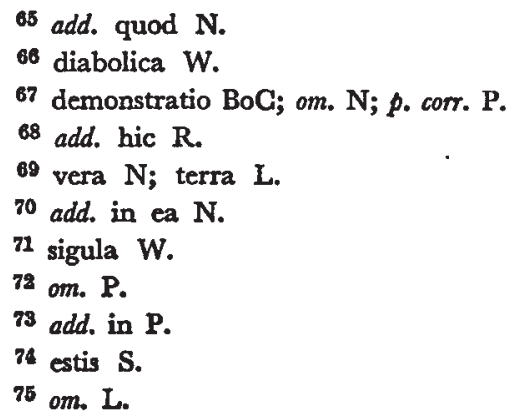

k Augustine, De Genesi ad litteram II, cap. 5; PL 34. 267.

1 Isaias 8: 16.

m John 8: 31, 
Sed quis est" discipulus? Luc. 14: "Qui non renuntiaverit omnibus quae possidet, non potest meus esse discipulus"."

Omnibus inquit, ${ }^{77}$ scilicet propriis voluntatibus in mente et voluptatibus in corpore - quia $a^{78} S a p$. 1: "In malivolam animam non introibit" sapientia" contra ${ }^{80}$ primum, "nec habitabit ${ }^{81}$ in corpore subdito peccatis" 82 contra secundum. ${ }^{\circ}$ Iob 28: "Nec ${ }^{83}$ invenitur ${ }^{84}$ in terra suaviter ${ }^{85}$ viventium".p

Cum quanta autem ${ }^{86}$ debeat audiri reverentia quis ${ }^{87}$ dicat? Dicit ${ }^{88}$ Ecclus. 13: "Dives locutus est, et omnes tacuerunt".q Deus deorum Dominus locutus est, et non omnes tacebunt. Dicit" Eccles. 9: "Verba sapientium audiuntur in silentio".r Quanto magis ${ }^{20}$ Dei a quo omni sapienti est sapientia? Ecclus. 1: "Omnis sapientia a Domino Deo est".s Basilius: "Qualis"1 igitur auditus dignus sit magnitudine relatorum, vel quemadmodum instructus debet esse animus ad rerum eiusmodi ${ }^{92}$ perceptionem? Nimirum qui vitiis carnalibus est immunis et aerumnis minime saecularibus obfuscatus, quin etiam ${ }^{93}$ laboriosus et sollers et omnia circumspectans, ut meritam ${ }^{94}$ Dei notionem possit attrahere".t

De quo autem ${ }^{95}$ sit haec tamquam de subiecto vel materia divisione investigandum. ${ }^{96}$ Tria quidem sunt ${ }^{97}$ simplicia: scilicet natura suprema, quae est Deus; et ${ }^{98}$ natura infima, ${ }^{99}$ quae est corpus; et ${ }^{1}$ natura media, scilicet rationalis creatura. Tria sunt insuper ex his composita: scilicet

76 add. eius $\mathrm{P}$.

77 om. BoCN.

78 om. Quia... corpore N.

79 intrabit $P$.

80 om. contra primum BoCSV; i.m. P.

81 hereditabit L.

82 peccatum $\mathbf{L}$.

83 Non BoCNPS.

84 invenietur LS.

85 suaviter: ovanter (?) in terra P.

$86 \mathrm{om}$. N.

87 quis dicat: quid dicatur $P$.

n Luke 14: 33.

- Wisdom 1: 4.

p Job 28: 13.

q Ecclesiasticus 13: 28.

r Ecclesiastes 9: 17.

s Ecclesiasticus 1: 1.

i Basil, In hexaemeron, hom. 1, cap. 1; Eustathius: ancienne version latine des neuf homélies sur l'Hexaemeron de Basile de Gésarée, ed. de Mendieta et Rudberg, in Texte und Untersuchungen (Berlin, 1958), LXVI, p. 4.
88 dicat $\mathrm{B}$.

89 dicitur CN.

90 add. verbum $\mathrm{N}$.

91 quantus SV.

92 huiusmodi BoCNPSV.

${ }^{93}$ et N.

94 veritatem B; cernitam (?) V.

${ }^{95}$ autem sit haec tamquam: fit theologia ut N.

96 add. est BoCV.

97 sint $\mathrm{O}$.

98 om. BoCNPS.

89 infinita W. 
compositum ex infima et media natura, homo ${ }^{2}$ scilicet $^{3}$ et compositum ex media et suprema, ex quibus ${ }^{4}$ fit illud unum de quo ${ }^{5}$ Apostolus Cor. 6: "Qui adhaeret Deo, unus spiritus est" — et hoc est unum, quod est Ecclesia, scilicet caput et membra; et tertium est ${ }^{6}$ quod ex omnibus his componitur naturis, scilicet Christus. Sex igitur ${ }^{7}$ sunt in universo.

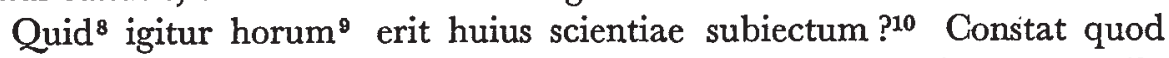
nec $^{11}$ natura infima tantum, nec ${ }^{12}$ media tantum, nec compositum ex media et infima. Multa enim ${ }^{13}$ de aliis tribus in hac scientia dantur, et forte plura quam de his. Ergo aliquod trium reliquorum erit huius subiectum. Et ponunt quidam unum, quidam alterum, quidam vero tertium.

Mihi' ${ }^{14}$ autem videtur quod de quolibet horum trium potest dici hanc scientiam esse sed tamen de unico eorum ut de subiecto. In aliis quidem scientiis videmus quidem ${ }^{15}$ aliquid ${ }^{16}$ esse minimum et aliquid subiectum $\mathrm{et}^{17}$ tertium summe compositum in illo genere. Sic ${ }^{18}$ dicitur geometria esse de puncto ut $^{19}$ de minimo suo; de magnitudine immobili ut de subiecto; de corpore ut de summe ${ }^{20}$ composito in illo genere. Dicitur ergo esse de puncto, quia a natura puncti ${ }^{21}$ fluit tota natura sui ${ }^{22}$ subiecti. Dicitur ${ }^{23}$ esse de corpore, quia prae sui compositione continet in ${ }^{24}$ se omnia quaecumque sunt sui subiecti ut punctum, ${ }^{25}$ lineam, ${ }^{26}$ superficiem,,${ }^{27}$ et dimensionem trinam.

Similiter aestimo hanc scientiam esse de Deo tamquam de minimo et indivisibili, a quo fluit quicquid est in subiecto huius scientiae. $\mathrm{De}^{28}$ Christo vero est ut de maxime composito habens ${ }^{29}$ in se quasi partes componentes quaecumque sunt in subiecto huius scientiae. Sed de illo uno, quod est ex ${ }^{30}$ natura media et suprema, est haec scientia tamquam de vero ${ }^{21}$ subiecto.

1 om. BoCNPS.

2 homo sc. et: ut homo N.

3 om. BoGLPS.

- p. corr. quo O.

5 om. R.

6 om. BN.

7 ergo $\mathrm{N}$.

8 Quod N.

om. CNSV.

10 add. et L.

11 non $O$.

12 om. nec media tantum L.

13 om. L.

14 nisi $W$.

$15 \mathrm{om}$. OW.

16 aliud $\mathrm{N}$.
17 add. aliquid L.

18 sicut BBoCLNSV.

19 om. ut... puncto N.

20 summo BoC.

21 primogeniti L.

22 om. N.

23 add. etiam $\mathrm{N}$.

24 om. in se N.

25 punctam L.

26 add. et $O$.

27 om. C.

28 om. De... scientiae $\mathrm{N}$; exp. De... scientiae $\mathbf{O}$.

${ }^{29}$ habente P.

30 om. N.

31 nullo $\mathrm{L}$.

u I Corinthians 6: 17. 
De quo uno ${ }^{32}$ Eph. ${ }^{33}$ : Omnes unum sumus in Christo. ${ }^{34 \mathrm{v}}$ Unde Io. 17, in ${ }^{35}$ fine, dicit Filius ad Patrem de discipulis: "Ego claritatem quam dedisti mihi, dedi ${ }^{36}$ eis: ut sint unum, sicut et $^{37}$ nos unum ${ }^{38}$ sumus"." Claritatem, id est sapientiam quae in sacra scribitur Scriptura. De qua Sap. 6: "Clara est, et quae numquam marcescit, sapientia", $x$ ut sint unum, scilicet nobiscum.

Sed ex hac auctoritate magis videtur quod hoc ${ }^{39}$ unum sit effectus et ${ }^{40}$ finis huius scientiae quam subiectum. Omnis autem scientia est de aliquo perfecto ${ }^{41}$ tamquam de subiecto et non efficit suum subiectum. Sed hoc verum est in his, quae speculativae ${ }^{42}$ tantum sunt, scientiis; sed in practicis idem est subiectum et finis. Practica enim est de operatione ut de subiecto. Et tamen operatio est finis quem ${ }^{43}$ intendit efficere, sicut ${ }^{44}$ domificativa est de domibus faciendis; et hoc est quod ipsa intendit efficere. ${ }^{45}$ Sic haec scientia quidem ${ }^{46}$ est de dicto ${ }^{47}$ uno tamquam de subiecto. Et in quantum speculativa est, docet et notificat hoc unum et partes huius ${ }^{48}$ unius tam subiectivas ${ }^{49}$ quam integrales et proprietates earum.

Sed quia non tantum stat in cognitione subiecti sed extenditur ad pra$x i m,{ }^{50}$ ad hanc ipsam, in quantum practica est, monet unitatem ${ }^{51}$ et vitare contrarium, ${ }^{52}$ scilicet peccata mortalia separantia hanc unitatem naturae mediae et supremae. Sicut dicit $I s .59:^{53}$ "Peccata vestra diviserunt inter vos et Deum vestrum". ${ }^{54 y}$ Sic $^{55}$ est $^{56}$ logica de syllogismo vel ${ }^{57}$ argumentatione; quam tamen docet construere.

Sed quaeris ${ }^{58}$ forsitan quia superius diximus hanc esse de omnibus, quo-

32 om. $\mathrm{N}$.

45 om. N.

33 cancell. G; i.m. Ro. XII 6 G; Apocalypsis S. ${ }^{40}$ om. S.

34 add. Gal. 3: Si omnes vos unum estis in Christo 47 Deo N. Iesu L.

$35 \mathrm{om}$. BoC; in fine dicit: $6 \mathrm{~N}$.

48 om. $\mathrm{N}$.

36 de N.

37 om. P.

38 om. BLR.

39 om. L.

40 om. et finis $P$.

1 prefecto BLORS.

49 subiectans $\mathrm{W}$.

60 practicam $\mathrm{N}$.

51 add. unitari $\mathrm{N}$.

62 contrariam L.

${ }^{53}$ add. in principio BO; add. principio LRW.

54 om. P.

55 sicut N.

42 speculativae: in speculativis N; speculatem W. ${ }^{56}$ ergo B; om. $\mathrm{P}$.

43 quam BoCPSV.

44 om. sicut... efficere L.

57 et $\mathrm{N}$.

58 quaeres $\mathrm{O}$.

v Ephesians 4: 1-16.

w John 17: 22.

x Wisdom 6: 13.

y Isaias 59: 2. 
modo nunc ${ }^{59}$ dicimus eam esse de subiecto quodam, ${ }^{60}$ quod non est omnia sed unum aliquod de omnibus. Sed ad hoc dicimus quod cum non sint in universo nisi sex quae diximus, scilicet tria simplicia ${ }^{61}$ et tria ex eis ${ }^{62}$ composita, si discutias singula, videbis quodlibet ${ }^{63}$ eorum esse vel partem subiectivam dicti subiecti vel integralem. Natura enim infima, scilicet corpus, est pars integralis hominis, qui ${ }^{64}$ est natura rationalis; et ideo natura media, quae est pars integralis dicti subiecti; similiter compositum ex tribus naturis, ${ }^{65}$ scilicet Christus. Sic ergo quamvis sit de omnibus, est tamen de uno aliquo ${ }^{66}$ tamquam de subiecto. Hinc patet quod inter omnes scientias haec sola sufficit satiare desiderium intellectus nostri, qui, ut supradictum est, desiderat naturaliter scire omnia.

De unitate autem huius scientiae videtur primo ${ }^{67}$ quod nulla sit. Dicit Philosophus quod unitas scientiae est ab unitate subiecti. ${ }^{2}$ Sed videtur quod subiectum eius ${ }^{68}$ non sit unum duplici ratione. Primo sic: ex his quae maxime distant non fit unum. Sed Creator et creatura maxime distant. Nulla enim ${ }^{69}$ creatura a quacumque alia tantum potest distare quantum Creator et creatura; immo in infinitum distant. Ergo ex natura suprema et media non fit unum.

Item $^{70}$ dicit Philosophus ${ }^{71}$ : Ex duobus quorum utrumque est ${ }^{72}$ actu non fit $^{73}$ unum. $^{\text {a }}$ Sed inter creaturas natura media est maxime ens ${ }^{74}$ actu, et natura suprema in ${ }^{75}$ infinitum magis ${ }^{76}$ est ens $^{77}$ actu. Ergo ex eis ${ }^{78}$ non fit ${ }^{79}$ unum. Ergo subiectum huius scientiae non est unum; ergo nec scientia una.

Solutio. Dico ad primum quod quia ${ }^{80}$ in infinitum distant, non ${ }^{81}$ propter hoc non sunt unibilia. Sed ${ }^{82}$ propter hoc $^{83}$ non sunt unibilia nisi a virtute infinita. Si enim virtus finita illa quae maxime distant - finite ${ }^{84}$

59 om. N.

${ }^{60}$ om. P.

61 principia L.

62 his $B$.

63 quolibet $W$.

64 qui: quia non $W$; quod $S$.

65 om. N.

68 add. omnium BLW.

67 om. BoCNPSV.

68 om. N.

69 om. L.

70 om. Item... unum B.

71 add. in Physicis BoCNPSV;i.m. in $7 \mathrm{Me}-$ taphysicae $P$.

72 add. in L.

73 fit unum: est unum actu $\mathrm{N}$.

74 om. $\mathrm{N}$; add. in L.

${ }^{75}$ et $\mathrm{N}$; om. in infinitum $\mathrm{P}$.

76 maius $N$.

77 add. in $\mathbf{R}$.

78 his BPS.

79 sit $\mathrm{N}$.

80 om. N.

82 nec N.

83 om. sed... unibilia BoCN; i.m. PS.

84 om. B.

z Aristotle: "Et scientia una est in qua est subiectum unum", An. post. I, 28. 87a38; Arit. Lat. IV, 3, p. 56.

a Cf. Aristotle: "Duo namque sic actu, numquam sunt unum actu", Meta. VII, 13. 1039a4-5; in Th. Aq., Omnia Opera, ed. Vives, 25, 22. 
tamen - unire potest, ut natura quaedam corporis, quinti scilicet ${ }^{85}$ caeli, unit aquam et ignem in mixto quae contraria sunt et ideo maxime distant (contraria enim sunt quae sub eodem genere posita maxime distant), similiter et consimilis vel eadem natura unit adhuc magis distantia, scilicet spiritum et limum, ut dicunt naturales, quid mirum si virtus infinita unire potest ea quae in infinitum distant? Haec autem virtus infinita non est nisi alterum unibilium. Unicum ${ }^{86}$ enim est quod infinitae est potentiae vel virtutis, scilicet natura suprema. Ergo ipsa natura suprema un.t se naturae mediae se ipsa, non ${ }^{87}$ aliquo alio.

Quod si ponatur hoc ${ }^{88}$ uniens $^{89}$ esse caritas: si Creator est, non est aliud ab eo quod ${ }^{90}$ diximus; si creatura est, non potest haec unire. Nihil enim creatum est infinitae virtutis. In infinitum autem distantium unio non fit ${ }^{91}$ nisi per virtutem infinitam. Sic ergo quia caritas ${ }^{92}$ qua diligit ${ }^{93}$ nos constat quod nihil aliud est quam ipsa natura suprema. $\mathrm{Haec}^{94}$ si unit, non receditur ${ }^{95}$ ab eo quod diximus, scilicet quod natura suprema unit se naturae mediae se ipsa. Caritas vero qua ipsum diligimus, si creatura est, non ${ }^{96}$ unit quidem ${ }^{07}$ haec, sed magis consequitur - immo, ut verius dicam, concomitatur hanc unionem. Non enim unit se Deus non-amanti, neque amanti ante unionem unitur postea, sed simul fit utrumque.

Ad secundum dico quod dupliciter est aliquid possibile vel ${ }^{98}$ non-ens actu: scilicet vel possibile potentia activa, ut materia naturalis habens in se aliquid formae, vel passiva tantum, ut tabula respectu picturae. Possibile autem potentia passiva tantum est dupliciter: ${ }^{99}$ scilicet possibile recipere aliquod naturale ${ }^{1}$ quod non habet vel gratuitum, scilicet ${ }^{2}$ quod est supra naturam. Dico ergo quod licet anima sit ens actu et ideo non possibilis respectu alicuius naturalis, est tamen possibilis respectu alicuius quod est supra naturam. Et sic ex ipsa $^{3}$ et illo quod est supra naturam, scilicet Deo, fit unum.

Hinc iam patet quod supra modum et $t^{5}$ incomparabiliter ${ }^{6}$ est haec scientia verius una quam aliqua ${ }^{7}$ alia. Est enim ${ }^{8}$ una ab unitate subiecti sui.

85 invicem $\mathrm{N}$.

81 om. LN.

86 unum N.

87 add. ab $\mathrm{O}$.

88 hic G.

89 om. L.

90 quem $N$.

91 sit $\mathrm{N}$.

22 add. qua diximus $\mathrm{S}$.

93 dilexit L.

94 add. ergo N.

95 recedatur BoN.
96 numquam $\mathrm{S}$.

97 om. S.

98 vel non: non et (m. post.) O.

99 duplex N.

$I$ materiale BoPV; $p$. corr. CS.

2 om. GNSV.

3 anima $\mathrm{N}$.

4 sit N.

5 om. P.

6 inopinabiliter $\mathrm{N}$.

7 alia (sic) W.

8 autem L. 
Subiectum autem est unum unitate supra naturam, unitate quidem virtutis infinitac unientis. Omnium autem aliarum scientiarum subiectum est unum unitate naturae et ideo per virtutem unientem ${ }^{9}$ finitam. Finitum autem ad infinitum non est ${ }^{10}$ comparabile.

Divisio autem huius scientiae sic est, quia in natura media duo sunt: scilicet virtus motiva et apprehensiva, quae dicuntur aliis nominibus affectus et aspectus. Natura autem suprema est bonitas summa et summa veritas. Ideo hacc scientia, quae est de uno ex duobus, habet partes duas: ${ }^{11}$ una est de unitate affectus cum summa bonitate, et alia est ${ }^{12}$ de unitate aspectus cum summa veritate.

Unitatem autem affectus ${ }^{13}$ cum summa bonitate in via concomitatur in medietate, sicut per se accidens suum per se subiectum, sanctitas morum; in patria vero fruitio omnium bonorum. Unitatem vero ${ }^{14}$ aspectus et summae veritatis, sicut possibile est in via, concomitatur in medietate, sicut per se passio subiectum, fides vel credulitas articulorum fidei; et in patria intellectus. Unde Is. 7: "Nisi'15 credideritis, non [alia ${ }^{16}$ littera] intelligetis". ${ }^{17}$ b Ideo huius scientiae pars illa, quae est de unione affectus cum sum$\mathrm{ma}^{18}$ bonitate in via, insistit moribus instruendis; pars vero alia, ${ }^{19}$ quae est de unione aspectus et summae veritatis in via, quaestionibus difficilibus circa articulos fidei discutiendis.

Una ergo pars est de sanctis moribus, alia ${ }^{20}$ de quaestionibus circa fidem difficilibus. Unde Ps. 48:21 "Os meum loquetur sapientiam, et meditatio cordis mei ${ }^{22}$ prudentiam".c Glossa:23 "Sapientia ad divina ${ }^{24}$ pertinet; prudentia ad mores. In his duobus ${ }^{25}$ omnis divinus sermo indicatur". ${ }^{\mathrm{d}}$ Haec est intellectus speculativi, ${ }^{26}$ illa practici summa perfectio sicut possibile est in via.

\footnotetext{
om. W.

10 om. S.

11 Et $\mathrm{N}$.

$12 \mathrm{om}$. N.

13 aspectus $\mathrm{N}$.

14 autem BoCNPV.

15 om. W.

16 om. alia littera L.

17 add. (i.m.) Tota theologia aut est de moribus instruendis aut de quaestionibus determinandis CP.

18 sua $B L$.

19 illa L.

20 add. est $\mathbf{R}$.

21 om. N.

22 om. LP.

23 om. L.

24 divinam L.

$25 \mathrm{om}$. N.

26 add. et $\mathrm{O}$.

b Isais 7: 9. Cf. Jerome: "“Si non credideritis, non permanebitis', ... vel certe iuxta LXX, 'non intelligetis'. Et est sensus: quia quae Dominus dicit futura, non creditis, intelligentiam non habebitis. Haec iuxta historiam dixerimus", Comm. in Isaiam Prophetam III, 7; PL 24. 104. c Psalms 48: 4.

d Peter Lombard, Commentarium in Psalmos, Ps. 48, vers. 3; PL 191. 466.
} 
Utraque fateor harum partium in sacro Scripturae sacrae $e^{27}$ canone sed indistincte - continetur. Verumtamen tantum ${ }^{28}$ altera pars, scilicet de moribus instruendis, a magistris modernis cum leguntur sancti libri docetur. Alia tamquam difficilior disputationi reservatur. Hacc autem pars difficilior de canone sacrarum ${ }^{20}$ Scripturarum excerpta ${ }^{30}$ in isto libro qui Sententiarum dicitur ponitur. Undesnon-differthicolegereet disputarea

Et quia" ${ }^{31}$ ut dicitur Sap. 1: "In malivolam animam non" introibit sapientia", ${ }^{\mathrm{e}}$ prius est ut affectus informetur sanctis moribus, quam aspectus desudet $^{33}$ in quaestionibus circa fidem difficilibus. Alioquin ${ }^{34}$ parum $^{35}$ aut nihil proficiet. ${ }^{36}$ Unde Tim. 6, principium: $:^{37}$ "Superbus est, ${ }^{38}$ nihil sciens, ${ }^{39}$ sed languens circa quaestiones et pugnas verborum". Quia ergo ${ }^{40}$ in praecedentibus ${ }^{41}$ de moribus instruendis audistis, ratio ordinis et consummationis exigeret ut et $^{\mathbf{t 2}}$ secunda pars, quae est de quaestionibus circa fidem difficilibus, nunc convenienter ${ }^{13}$ legeretur. ${ }^{44}$

Sed ad tantam sublimitatem imperfectum meum viderunt oculi vestri ${ }^{45}$ - et non unicam imperfectionem sed duplicem, scilicet imperfectionem scientiae in mente et virium in corpore. Tamen ${ }^{46}$ oboedientiam nec $^{47}$ valens nec volens declinare, confidentiam habeo in eo de quo dicitur, Ecclus. 15: "Quoniam multa est sapientia Dei, et fortis in potentia".g Est enim Dei virtus et Dei sapientia, sicut dicitur Cor. $1{ }^{48 \mathrm{~h}}$ confidens quod ipse Dei $^{49}$ virtus vires subministrabit ${ }^{50}$ quas denegat natura, et ipse ${ }^{51}$ Dei sapientia scientiam quam denegat imperitia. In ipso ergo qui est "Alpha et Omega, principium et finis", Apoc. 1,1 spem inceptionis et consummationis tanti laboris ponentes, revertimur ad propositum.

27 om. BoCNSV; sitire (sic) L.

28 om. P.

29 om. N.

80 excepta $N$.

81 om. L.

32 vero $W$.

33 desuadet $L$.

34 add. aut $\mathrm{L}$.

35 parvum $N$.

${ }^{36}$ perficiet $\mathrm{C}$.

37 om. BoCNPV.

38 om. BoCNV.

39 faciens L.

e Wisdom 1: 4.

f I Timothy 6: 4.

g Ecclesiasticus 15: 19.

h I Corinthians 1: 24-25.

i Apocalypse 1: 8.

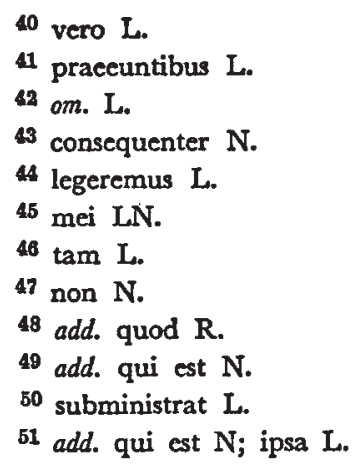


Diximus $^{52}$ secundam ${ }^{53}$ partem huius sacratissimae scientiae, scilicet quae est de difficilibus circa fidem quaestionibus, in hoc ${ }^{54}$ libro contineri:55 qui primo dividitur in partem prooemialem et executivam. Quia vero quidam articuli fidei ${ }^{56}$ sunt de rebus, quidam vero de rerum signis, utpote de sacramentis, ideo liber iste quo ad partem executivam primo dividitur in partes duas. In prima parte tracțantur quaestiones difficiles de articulis fidei quae circa res versantur; et haec ${ }^{57}$ pars continet 3 libros. In secunda quaestiones difficiles ${ }^{58}$ de articulis fidei quae sunt circa signa, scilicet circa sacramenta; et haec pars traditur in quarto libro.

Prima autem pars, quae pertractat ${ }^{59}$ quaestiones difficiles circa res, dividitur in partes 3. Tripliciter enim ${ }^{60}$ sunt res circa quas versatur fides, quia res aut sunt ${ }^{61}$ Creator, aut creatura, aut ex utroque composita.62 De quaestionibus difficilibus circa Creatorem est primus liber. De quaestionibus circa creaturas $^{63}$ est secundus liber. ${ }^{64}$ De quaestionibus circa Christum, qui ex Creatore et creatura est compositus, est tertius liber.

Cupientes AliQUID, ${ }^{65}$ et cetera. Haec pars prooemialis dividitur primo in partes 4 secundum 4 causas. Huius autem partis divisionem, utoculis facilius occurrant ${ }^{66}$ singula, ${ }^{67}$ in modum arboris ramosae depingimus, $7 u t$ tamquam ex radice stipites, ex stipitibus rami, ex ramis ramusculi, a quibus folia et fructus egrediantur. ${ }^{68}$

Fairfield University.

Fairfield, Connecticut.

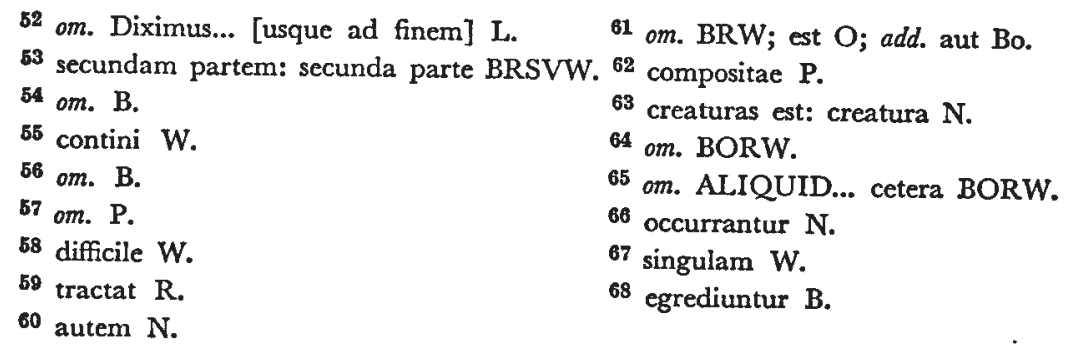

